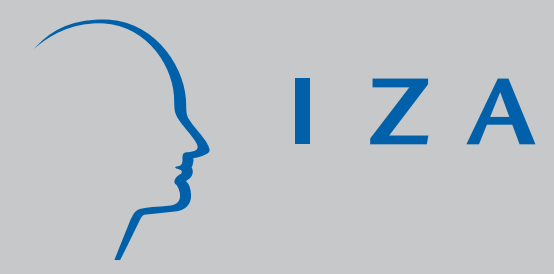

IZADP No. 3401

What Are the Factors Behind Pay Settlements?

Evidence from Spanish and British Data

Alberto Bayo-Moriones

J ose E. Galdon-Sanchez

Sara Martinez-de Moretin

March 2008 


\title{
What Are the Factors Behind Pay Settlements? Evidence from Spanish and British Data
}

\author{
Alberto Bayo-Moriones \\ Universidad Publica de Navarra \\ Jose E. Galdon-Sanchez \\ Universidad Publica de Navarra and IZA \\ Sara Martinez-de Moretin \\ Universidad Publica de Navarra
}

Discussion Paper No. 3401

March 2008

\author{
IZA \\ P.O. Box 7240 \\ 53072 Bonn \\ Germany \\ Phone: +49-228-3894-0 \\ Fax: +49-228-3894-180 \\ E-mail: iza@iza.org
}

\begin{abstract}
Any opinions expressed here are those of the author(s) and not those of IZA. Research published in this series may include views on policy, but the institute itself takes no institutional policy positions.

The Institute for the Study of Labor (IZA) in Bonn is a local and virtual international research center and a place of communication between science, politics and business. IZA is an independent nonprofit organization supported by Deutsche Post World Net. The center is associated with the University of Bonn and offers a stimulating research environment through its international network, workshops and conferences, data service, project support, research visits and doctoral program. IZA engages in (i) original and internationally competitive research in all fields of labor economics, (ii) development of policy concepts, and (iii) dissemination of research results and concepts to the interested public.
\end{abstract}

IZA Discussion Papers often represent preliminary work and are circulated to encourage discussion. Citation of such a paper should account for its provisional character. A revised version may be available directly from the author. 


\section{ABSTRACT}

\section{What Are the Factors Behind Pay Settlements? Evidence from Spanish and British Data}

This article presents a study of the determinants of pay settlements in a sample of Spanish and British establishments. We find that variables such as establishment size and age, foreign ownership, labour costs, the existence of internal labour markets, a strategic approach to human resource management and pay setting institutions are related to the factors that shape pay adjustments. Moreover, our findings show that there are significant differences in the determinants of pay settlements between Spain and Great Britain. We suggest that the labour market institutions developed in each country influence pay setting decisions.

JEL Classification: J30, J40

Keywords: compensation systems, labor market institutions, wage settlements, establishment level data

Corresponding author:

Jose E. Galdon-Sanchez

Department of Economics

Universidad Pública de Navarra

Campus Arrosadía

31006 Pamplona (Navarra)

Spain

E-mail: jose.galdon@unavarra.es

\footnotetext{
* The authors acknowledge the Department of Trade and Industry, the Economic and Social Research Council, the Advisory, Conciliation and Arbitration Service and the Policy Studies Institute as the originators of the 2004 Workplace Employment Relations Survey data, and the Data Archive at the University of Essex as the distributor of the data. The National Centre for Social Research was commissioned to conduct the survey fieldwork on behalf of the sponsors. None of these organisations bears any responsibility for the author's analysis and interpretations of the data. The authors also thank the Fundacion BBVA for the funding of the survey conducted in the Spanish establishments. This paper has been prepared for the BJIR Conference on Comparative Studies of the Workplace to be held on March 13 and 14 in the Centre for Economic Performance at the London School of Economics. Galdon-Sanchez acknowledges financial support from Ministerio de Educacion y Ciencia, project SEJ2005-03470/ECON.
} 


\section{Introduction}

The design of compensation systems in organisations is a topic that has been extensively studied in the literature. The relevance of studying compensation systems rests on the fact that they constitute a fundamental component of the employment contract. As Bryson and Forth (2006) point out, pay is not only the result of an economic transaction consistent of trading worker effort for a certain reward. Bargaining processes between employees and employers, no matter at which level take place, frequently influence wage levels. Labour market institutions and political decisions adopted by governments also shape the rewarding practices of firms. Moreover, employers use payment policies as a valuable tool for managing the workforce and, for example, motivate workers to exert a desired level of effort. All these indicate that pay determination is a complex process, which is the result of different influences.

As an important element of the employment relationship, wages are reviewed when changes in the terms of this relationship occur. Pay reviews are costly for employers. This implies that, instead of being designed on an individual basis, they are frequently carried out with a certain periodicity, embracing groups of workers. This type of wage adjustments, known as pay settlements, is the centre of our analysis. Whereas the determinants of wage levels have been widely analysed, both empirically and theoretically (see, for example, Werner and Ward, 2004, for a review of the literature on this topic), little effort has been made to ascertain what the variables that influence pay settlements are. Among the most recent research on this topic we find the work by Ingram et al. (1999), who analyse the incidence of external factors, such as comparability, as well as internal influences, like firm performance, on the size 
of wage settlements in Britain. Likewise, Forth and Millward (2000) examine the factors that shape the size of pay settlements for a sample of British workplaces. Taking elements from the theories of pay determination, they investigate how changes in several variables such as the cost of living, the demand and supply of labour or the establishment performance affect wage adjustments. Brown et al. (2004) study the issue of nominal wage rigidity in Britain, considering the influence that labour market institutions, unions, the cost of living and firm performance exert on wage adjustment processes.

This paper aims to contribute to the literature on pay settlements taking an approach to the issue that is somehow different to the one adopted by the aforementioned authors. We focus on studying the influence that a range of plant characteristics has on the importance given by employers to various factors when setting pay. As well as investigating establishment-level variables, we also examine the role that labour market institutions play in the process of pay determination. Employers' decisions on employment matters are undoubtedly constrained by institutions such as statutory minimum wages, employment protection legislation or the institutional features of wage bargaining. Therefore, we can not fully understand pay setting decisions at the establishment level without considering the influence exerted on them by labour market institutions. Moreover, by improving our knowledge on how employers determine wage adjustments and on how labour market institutions influence this decision, we will obtain valuable information that could eventually help to design new labour market policies. These new policies could also contribute to reach some desired macroeconomic goals, such as the reduction of wage inequality or the rate of unemployment. 
An additional novelty of this work relays on the fact that, in order to carry out our research, we perform an empirical analysis using data from two different surveys. One of them is the well-known Workplace Employment Relations Survey 2004 (Department of Trade and Industry, 2005), a study on industrial relations and employment practices across Great Britain. The other is a newly created Spanish data set on human resource management practices, which has its origin on a survey conducted in 2006 for a representative sample of Spanish manufacturing establishments. The fact that we have chosen Spain and the UK to perform our study is not a coincidence. Well to the contrary, we have particularly chosen to compare these two countries since they have developed very different institutional scenarios, with the system of industrial relations in the UK being scarcely regulated whereas Spain has one of the most regulated systems in the world. Therefore, the study of these specific countries constitutes a unique opportunity for evaluating the role of labour market institutions in the pay setting processes.

The UK system of industrial relations is usually referred to as voluntarism, term that makes reference to the aforementioned scarce legal regulation of employment relations and the voluntary character of collective bargaining that is visible in that country. In Spain, however, labour relations are highly regulated and collective bargaining affects a larger amount of workers. In addition, both countries experienced important political changes with implications for labour market institutions at approximately the same time. Spain underwent a shift in government in 1996, when the conservative party won the elections after more than 12 years of socialist party ruling. Only a year later, the Labour Party won the elections in the UK. The political decisions adopted by 
both new governments entailed a restructuring of their economies and, in particular, implied changes in their respective labour market policies (see Hamann and Kelly, 2003). Given these facts, we consider that relevant conclusions can be obtained from the comparison of these two countries in relation to the debate at hand.

Our empirical strategy starts with the specification of a diverse set of hypothesis that we consider may play a role in the process of pay adjustment. The subsequent empirical analysis will have to corroborate or not those hypothesis. Specifically, we examine the implications for pay setting of establishment size and age, foreign ownership, the proportion of labour costs, the presence of internal labour markets, the existence of a strategic approach to human resource management (from now on HRM), and the mechanism of pay determination. As we have mentioned above, we also analyse the influence of labour market institutions on the variables of interest. The factors considered in the determination of pay settlements analysed in this paper are the changes in the cost of living, the ability to recruit or retain employees, the performance of the organisation and the industrial relations climate.

We find that, when setting pay, establishments of a large size give less importance to the climate of industrial relations than small establishments. The age of the establishment is positively correlated with the importance given to inflation and to the performance of the plant. In their decisions concerning wage adjustment, foreign-owned establishments take the cost of living into account, but they are less concerned about their ability to recruit and retain employees and about their performance than other establishments. Workplaces with low labour costs and those without internal labour markets give more importance to 
recruitment issues when setting pay. The absence of internal labour markets is also positively correlated with the importance given to the social climate. An strategic approach to HRM implies that the performance of the plant is considered relevant for pay settlements. As for the mechanisms of pay determination, the existence of a collective agreement at sector level results in the establishment giving less importance to the cost of living, whereas in workplaces where a mechanism other than collective bargaining operate, employers are less concerned both about inflation and the climate of industrial relations. In addition, our results provide evidence which supports the hypothesis that the differences in labour market regulation between Spain and the UK influence the process of pay determination, as British establishments are less concerned about all the factors we have considered in our analysis.

The rest of the paper is structured as follows. Section two presents a theoretical examination of the factors that may determine pay settlements. Section three focuses on the description of the data sets used to perform our empirical exercise. In sections four and five we concentrate on the definition of the variables used in the study and present the main findings, respectively. Section six concludes. 


\section{Theoretical Background}

In this section we review the different hypotheses that are going to be tested in our empirical analysis. In what follows, we analyse the implications for our study of variables such as Establishment Size and Age, Foreign Ownership, Labour Costs, Internal Labour Markets, Strategic HRM, Mechanisms of Pay Determination and Labour Market Institutions.

\section{Establishment Size and Age}

The relationship between firm size and wages has been widely studied in the past. As a consequence, there exists abundant literature on this topic, revealing the existence of a positive effect of firm size on worker's wages. The presence of this firm-size wage premium has deserved several explanations (see Belfield and Wei, 2004; or Lallemand et al., 2005, among others). Reviewing these explanations could give us some insight on the determinants of wage adjustments in an establishment.

It is frequently argued that large firms display more advanced technology and greater capital intensity, so they require a more skilled and specialised workforce. Moreover, monitoring becomes more difficult as the size of the establishment increases (Schmidt and Zimmerman, 1991). Therefore, it could be expected that, when setting payments, large firms are more concerned about their ability to hire and retain employees. This is due to their requirements of qualified labour and to their need to motivate workers in order to avoid shirking.

As Oi and Idson (1999) point out, larger establishments provide better working conditions for employees. They generally offer more fringe benefits, safer and cleaner work environments, and a larger amount of specific training. Moreover, the probability of survival is higher for large firms. Consequently, 
employment in these workplaces is expected to be more stable and more satisfactory for workers. The conjunction of all these elements points to the direction of a better climate of industrial relations, which suggests that employers in big establishments don't need to use pay adjustments as a means of avoiding industrial conflict.

Hypothesis 1: When taking their pay setting decisions, large establishments give more importance to their ability to recruit and retain employees than smaller ones.

Hypothesis 2: When setting pay, large establishments are less concerned about the climate of industrial relations than smaller ones.

The relationship between establishment age and wages has also been broadly analysed in the literature. Brown and Medoff (2003) review some of the implications of the age of the establishment in order to get conclusions about its influence in wage determination. The authors report that, controlling for plant and firm size, older firms have lower probability of bankruptcy than younger ones (as in Brock and Evans, 1986). They also state that it is frequent for workers to develop their career within a single company and, consequently, older firms are characterised by having longer-tenured and more experienced workers (as in Farber, 1998; or Hall, 1982). Moreover, these firms generally offer better and more stable employment conditions, which range from job security, firm-specific training and higher and steeper wages to non-monetary compensation, like pensions and health insurance. In summary, workers in older firms usually have closer links with the organisation and enjoy better 
working conditions and benefits. As we have hypothesised for large plants, this can result in higher satisfaction for workers and, as a consequence, in an improved climate of industrial relations.

It can also be argued that the age of a firm is correlated with its ability to pay because, as Brown and Medoff (2003) point out, companies that have been operating for a long time are "those with the greatest underlying profitability". The ability to pay hypothesis allows us think that employers in old firms show less resistance to workers' wage requests and could choose to share their rents with employees. Whether the rent-sharing occurs as a way to motivate workers to work harder or in order to avoid conflict at the workplace, we expect to observe a correlation between the age of establishment and the consideration of performance in wages setting.

Hypothesis 3: When setting pay, old establishments give more importance to their performance than younger ones.

Hypothesis 4: When taking their pay setting decisions, employers in old establishments give less importance to the climate of industrial relations than employers in younger plants.

\section{Foreign Ownership}

Multinational companies operate in different countries, where they can encounter diverse institutional settings. As a result, they face the challenge of developing a strategy for managing human resources in an international context. The institutional environment of the country in which the subsidiaries operate and its differences with the environment of the country in which the 
parent firm develops its activity could and should affect multinationals' decisions regarding their choice of HRM practices (Gooderham et al., 2006).

The issue of the influence of institutional forces on HRM in multinational corporations (from now on MNCs) has been analyzed by Poutsma et al. (2006). The authors point out that organizational practices in MNCs are the result of the internal and external pressures that these firms confront. On one hand, MNCs face the challenge of adapting to the local environment to gain legitimacy. On the other, multinational companies, in order to follow a global HRM strategy, can obtain a competitive advantage if they keep some organisational coherence in the practices adopted across the various subsidiaries (see Kostova and Roth, 2002).

Consequently, due to the challenge of operating in an international environment, MNCs develop more complex HRM systems. As a result, we expect to find differences between those establishments that belong to a multinational group and those that do not regarding the importance that they give to their ability to recruit and retain employees. In addition, if we assume that the subsidiaries of a multinational compete among them, they need to maintain a certain level of labour productivity (see Morton and Siebert, 2001). This implies that these companies will be more interested in hiring the right workers and, consequently, they will take this into account when adjusting wages.

Hypothesis 5: In their pay setting decisions, foreign-owned establishments are more concerned about their ability to recruit and retain employees. 


\section{Labour Costs}

When designing pay policies, another variable that will be taken into consideration at the establishment level is the proportion of labour costs over total cost of production. Therefore, a relevant question for our work concerns the correlation between labour costs and wage adjustments.

In those establishments where labour costs represent a small proportion of production costs, labour is a relatively unimportant factor in comparison with capital. Capital-intensive firms need to hire more skilled and specialised workers in order to operate advanced technologies. This implies that the costs of turnover and shirking are higher in capital-intensive firms than in labourintensive firms. Therefore, it can be the case that firms with low labour costs are more concerned about personnel matters. Moreover, we can assume that, in establishments where labour costs constitute only a small fraction of production costs, changes in wages are relatively insignificant in comparison with establishments where the costs of personnel are higher. In the former, employers can be more flexible regarding their pay policies as wage increases do not imply significant variations in total costs (see Arai, 2003). As a consequence, it seems plausible to think that satisfying workers wage requests will be easier for employers with low labour costs. Taking all these factors into account, in pay setting decisions we expect to observe a negative correlation between labour costs and the importance given to personnel goals, such as recruiting and hiring needs.

Hypothesis 6: When setting pay, establishments with low labour costs are more concerned about their ability to recruit and retain employees. 


\section{Internal Labour Markets}

Many firms are characterised by having internal labour markets, where employees' careers develop basically within a single organisation. Hiring for the lower levels of the hierarchy is done at a small number of entry ports and jobs at higher levels are filled through internal promotion. Enduring employment relations, established career paths and on-the-job training are among the most cited features of these companies (see Brickley et al., 1997).

The existence of internal promotions as well as employment stability can be an incentive for applicants to enter the firm as well as for workers to remain inside the organisation. Employment relations terms are often determined internally by formal rules and procedures instead of being governed by market conditions. This implies that employees in these organisations are sheltered from external influences in the labour market. Then, it is possible that organisations with internal labour markets don't need to use pay as a mechanism of hiring and retaining employees.

Internal labour markets are also frequently characterised by the development of efficient ways to resolve disputes through grievance procedures and due process arrangements, which contribute to generate a harmonious working environment (Baron and Kreps, 1999). Therefore, it may be the case that, other than using the process of pay determination, the presence of an internal labour market within an organisation implies the existence of means to ensure a good work environment. 
Hypothesis 7: In their pay setting decisions, establishments with internal labour markets are less worried about their ability to recruit and retain employees.

Hypothesis 8: The existence of an internal labour market within an establishment implies that the climate of industrial relations is considered a less important variable for pay determination.

\section{Strategic Human Resource Management}

In the last decades companies have started to consider HRM as a fundamental asset, as well as one of the determinants of its success or failure. At the same time, human resource professionals have seen their participation in decision making processes increased, as their involvement in organisational strategy is considered to be key to successful HRM (see Baron and Kreps, 1999). Growing empirical literature has supported this idea. As a result, a new and strategic approach to human resource management has emerged in contrast to more traditional personnel practices (see Mesner-Andolsek and Stebe, 2005).

Strategic HRM implies the participation of the HR function in the development of the organisation's strategy through the common personnel activities of recruiting, selecting, training, evaluating and rewarding. The scale of strategic HRM in a firm can be measured by the implication of HR professionals in strategy formulation and implementation (Farndale, 2005). As Schuler and Jackson (2005) point out, this approach to HRM is based on the idea that "human resource management activities should contribute to business effectiveness" and, to do so, it is needed that HRM activities are linked to the objectives of the organisation. As we have mentioned above, the design of 
appropriate compensation systems is included in the function of HRM. Consequently, establishments willing to adopt a strategic approach to HRM will design their pay policies accordingly. In particular, our tentative hypothesis is that they will tie pay adjustments to their performance in order to align wages with the particular needs of the workplace.

Hypothesis 9: Establishments that adopt a strategic HRM approach give more importance to their performance when they set payments.

\section{Mechanisms of Pay Determination}

Pay determination arrangements impose restrictions on the wage structure of firms. In some organisations, working conditions and, particularly, pay policies are the result of bargaining processes between employers and workers' representatives, resulting in the application of agreements that regulate the employment relationship. Collective bargaining can take place at different levels, and the interests pursued and the agreements reached may vary depending on the level at which negotiation takes place. On the contrary, there are organisations in which pay is set unilaterally by management following considerations that can be very different from those of companies covered by collective agreements. Previous studies on this topic have shown that the mechanism of pay determination influence various dimensions of pay policies, specially wage levels and wage dispersion (see Plasman et al., 2007; Canal Domínguez and Rodríguez Gutiérrez, 2004; and Cardoso and Portugal, 2003, among others). Taking all this into account, we expect that bargaining regimes are correlated with the factors that employers take into account when setting pay. 
It is reasonable to think that, if employees have the possibility of bargaining wage adjustments with employers, they will fight for maintaining their purchasing power. If this is the case, then it also seems reasonable that the cost of living is considered more important when taking pay setting decisions in those establishments where a collective agreement exists, whether it is at plant, organisation or sector level, than in those establishments where pay is determined by some other mechanism.

Finally, we predict a positive relationship between the existence of a collective agreement (at sector, organisation or plant level) and the importance given to the industrial relations climate when setting pay. This is due to the fact that collective bargaining commonly pursues the establishment of harmonious employer-employee relations, and consequently reflects an underlying concern on the employer's side regarding the importance of creating a good work environment. Moreover, employees can see the processes of bargaining as a mechanism to express their voice in employment matters, which will eventually contribute to the existence of good relations with the management.

Hypothesis 10: When setting payments, establishments covered by a collective agreement at plant, firm or sector level give more importance to inflation.

Hypothesis 11: In their pay setting decisions, establishments covered by a collective agreement at plant, firm or sector level are more concerned about the industrial relations climate. 


\section{Country Effects}

In order to examine the influence of labour market institutions in the determination of payments, we describe the most relevant aspects of the industrial relations system in Spain and the UK. We also report the main political decisions adopted in these countries concerning labour market regulation during the years prior to the collection of the data sets used in our analysis.

Spain features a highly regulated labour market. Collective bargaining is governed by the Constitution of 1978 , which guarantees the right to collective bargaining between workers' representatives and employers, and protects the binding power of agreements. The structure of collective bargaining is quite fragmented. Workers not affected by bargaining at the firm level are covered by a sectoral agreement at national or regional level. Collective agreements are extended by law to non-affiliated firms or workers belonging to the area of negotiation (see Canal Domínguez and Rodríguez Gutiérrez, 2004). As a result, bargaining coverage in Spain is high ${ }^{1}$.

During the years of socialist government, employment protection in Spain was considerably high. The conservative party tried to make employment conditions more flexible with a reduction of the severance payments and the employers' contributions to social security, and facilitating the dismissal of permanent workers. However, after all these changes, employment protection in Spain remains high. According to OECD's ranking of the strictness of employment legislation (see OECD, 2004), in a scale ranging from 0 to 6 Spain had a punctuation of 3.1 in 2003 , whereas the score for the UK in this year was 1.1. As for industrial conflict issues, according to the European Industrial 
Relations Observatory (2007), strike activity in Spain is important in comparison with other EU countries and pay issues seem to be the main reason for it.

The system of industrial relations in the UK is characterised by the scarce legal regulation of employment relations and the voluntary character of collective bargaining. Collective agreements are not enforceable by law. The deregulation of the British labour market was particularly noticeable during the 1980s and 1990s with the conservative government. Hence, several laws were passed in this period with the aim of limiting trade union power and restricting collective bargaining. In 1997, with the arrival to power of the labour party, some important measures concerning labour market regulation were adopted, although many of the policies in place from previous years remain unchanged (Hamann and Kelly, 2003). Moreover, collective bargaining continues to be highly decentralised and scarcely co-ordinated, and takes place at sector, workplace or, more frequently, at company level. The Employment Relations Act of 1999 (in what follows ERA 1999) introduced a statutory union recognition procedure, but its impact has been limited and overall collective representation has continued to decline in recent years ${ }^{2}$.

As for wage determination, the decline in collective industrial relations initiated in 1979 has diminished the role of collective bargaining as the instrument used to set pay for employees. As a result, British employers have more freedom now to determine wage increases without being restricted by a strong regulatory framework. This is in contrast with the Spanish case, where pay increases are determined strongly by collective bargaining, commonly at sectoral level. The fact that in the UK the process of wage negotiation is more decentralised, and frequently determined unilaterally by management, takes us 
to think that British establishments will find it easier to link pay adjustments to the results of the workplace.

During the government of Margaret Thatcher, employment protection was significantly reduced with an increase in the qualifying period for protection against unfair dismissal and a decrease in dismissal costs. The ERA 1999 increased employment protection to a certain extent with measures such as an increase in maximum compensation for unfair dismissal and a slight reduction in the period of tenure necessary to enjoy employment protection rights. However, some aspects of employment protection inherited from the period under conservative government remain unchanged, so protection in the UK continues to be low (see Morton and Siebert, 2001). Therefore, the employment contract is more flexible in the UK than in Spain, suggesting that hiring and retaining the right workers is an issue of higher importance for Spanish employers than for British ones.

Another relevant aspect of a system of industrial relations is the climate of employment relations. During the conservative government, strong restrictions were imposed on union organisation and on industrial action as a mechanism of defence of the terms and conditions of employment. Moreover, compulsory unionism was outlawed. The New Labour government maintained the restrictions to strike activity. According to the European Industrial Relations Observatory (2007), compared to other EU countries, industrial conflict in the UK is relatively low. Therefore, it seems plausible to assume that when setting pay, Spanish establishments will be more concerned about industrial action than establishments in the UK, since in the latter country the climate of 
employment relations seems to be less conflictive and union activity is more restricted.

Hypothesis 12: When setting pay, British establishments are less concerned about their ability to recruit and retain employees than Spanish workplaces.

Hypothesis 13: When setting pay, the performance of the organisation or the workplace is a factor that British establishments take more into account.

Hypothesis 14: When setting pay, British establishments give less importance to the climate of industrial relations than Spanish plants.

\section{Data Description}

Our analysis is based on data from two sources. The first one is a Spanish data set collected in 2006 as part of a survey on HRM in the Spanish manufacturing industry. The second data base is the WERS 2004, which comprises a nationally representative sample of British establishments that provides information about the organisation of management-employee relations, and its impact on employer performance.

\section{Spain}

The Spanish data was gathered in 2006 through personal interviews with managers in manufacturing plants with fifty or more employees, and represents a unique source of information about diverse practices in Spanish firms. The project was intended to be a partial continuation of a previous study on HRM 
and operations management carried out in 1997. Information was collected at the plant level, the unit at which decisions about the implementation of the practices of interest are taken. Furthermore, knowledge of the issues included in the questionnaire is expected to be greater at plant level and, as a consequence, the data obtained should be more reliable.

Once defined the objectives and scope of our study, and in order to properly design the questionnaire, a thorough examination of the literature related to the purpose of the project was carried out. With the information gathered, a first draft of the questionnaire was drawn up jointly by the members of the research group and the firm in charge of the fieldwork. The questionnaire was pre-tested in nine plants and then modified in several ways to come up with its final version.

The final version of the questionnaire consists of 152 questions grouped in the following eight sections: General Characteristics of the Plant and the Firm, Human Resources, Payment Systems, Work Organisation, Human Resource Outcomes, Human Resource Function, Other Groups of Workers and Characteristics of the Plant Manager. Most of the information on HRM refers exclusively to blue-collar workers, that is, those workers involved directly in the production process. The reason for restricting the analysis to this category of employees lies on the existence of diverse internal labour markets with different features within the same organisation. Limiting the study to manual workers must facilitate comparisons across establishments.

The data was drawn from personal interviews with one of the managers at the plant. At first, it was thought that questions should be addressed to the general manager or to the human resource manager. Finally, it was decided 
that any manager at the plant was qualified to complete the questionnaire, being the human resource manager the figure most frequently interviewed.

The universe of potential respondents for the purposes of the project was constituted for all Spanish manufacturing establishments with fifty or more employees in 2005, which amounts to 6.971 units. The aim was to obtain a sample of one thousand units, in order to get conclusions that could be extended to the entire Spanish manufacturing industry. After stratification by sector, size and location, a random selection of workplaces was obtained from the Spanish Central Directory of Firms (Directorio Central de Empresas, DIRCE) of the Spanish National Statistics Institute (Instituto Nacional de Estadística, INE), using data from 2005.

The interviews with those managers that agreed to answer our questionnaire were performed by specially trained professionals using computer assisted telephone interviews (CATI). The establishments were first approached by a letter or an email indicating the goals of the survey and including a copy of the questionnaire.

\section{Britain}

The British data come from the WERS 2004, the fifth round of a series of surveys that have mapped industrial relations and employment practices in Great Britain since 1980. The survey collects information from managers with responsibility for employment relations or personnel matters, trade unions or employee representatives and employees themselves. It covers both private and public sectors and almost all industry sectors. Analogously with the Spanish survey, the unit of analysis is the workplace or establishment. 
WERS 2004 follows the line of previous rounds with both a CrossSection and a Panel element, and maintains the core questions so that comparisons with prior data sets are possible. However, some innovations have been introduced in the design of the new questionnaire. An important new element is the inclusion in the scope of the analysis, for the first time, of workplaces with between five and nine employees, which expands the reference universe to 700,000 workplaces (33 per cent of all workplaces in Britain).

For the purposes of this study, information was taken from one of the WERS sources, the Cross-Section Management Questionnaire. The main element of this survey was an interview with the senior manager at the workplace with a day-to-day responsibility for employment relations. The interview contains questions on the following 12 topics: Establishment and Organisation Characteristics; Management of Personnel and Employment Relations; Recruitment, Training and Organisation of Work; Consultation and Communication; Representation at Work; Payment Systems and Pay Determination; Collective Disputes and Procedures; Grievance and Disciplinary Procedures; Fair Treatment at Work; Establishment Flexibility; Establishment Performance and Workplace Change.

The sample for the Cross-Section was constructed using the InterDepartmental Business Register (IDBR), maintained by the Office for National Statistics. After stratifying the sample by workplace size and industry, workplaces were randomly selected from within a particular size brand and industry. The intention was to conduct interviews in 2,500 workplaces as part of the Cross-Section Survey. In the end, a total amount of 2,295 valid interviews 
with managers were obtained (see Kersley et al., 2006 for more information on the WERS 2004).

Finally, it is worth mentioning that prior to perform any regression, and in order to be able to compare plants with similar characteristics, we selected for the British sample only those establishments belonging to the manufacturing sector.

\section{Variables}

In what follows we describe the variables used in the empirical analysis. The sample means, standard deviations and definitions of the variables are presented in Table 1.

Both the Spanish and British questionnaires provide information on the factors that influenced pay settlements in the establishments surveyed. The four factors considered are Changes in the cost of living, Ability to recruit or retain employees, Performance of the organisation or workplace and Industrial relations climate. In the Spanish questionnaire, respondents were required to value the importance given to these factors when determining pay in a scale ranging from 0 (not important) to 10 (very important). In the British survey, managers were asked if the factors mentioned above influenced or not the size of pay settlements or reviews. In order to merge the information from both data sets, it was necessary to recode the Spanish scale variables into dichotomous variables. The transformations we considered to be more plausible are the following: 
- Values 0 to 4 in the Spanish questionnaire $\rightarrow$ Factor not taken into account when setting pay; values 5 to $10 \rightarrow$ Factor taken into account when setting pay.

- Values 0 to 5 in the Spanish questionnaire $\rightarrow$ Factor not taken into account when setting pay; values 6 to $10 \rightarrow$ Factor taken into account when setting pay.

- Value 0 in the Spanish questionnaire $\rightarrow$ Factor not taken into account when setting pay; values 1 to $10 \rightarrow$ Factor taken into account when setting pay.

We performed the estimations using the three transformations of the variables, and the differences in the results obtained were negligible. Eventually, we opt for the third recodification as we considered it to be the most consistent with the dichotomous measures of the dependent variables.

The set of covariates which are relevant to our analysis are the following:

- Establishment size: both surveys provide information on the number of workers employed at each establishment. We include the logarithm of the number of employees in order to control for possible size effects.

- Age of the establishment: British respondents were asked for how many years the establishment had been in operation. In the Spanish questionnaire, managers reported the year of foundation. We include a variable that informs of the log of the number of years in business for each plant.

- Ownership: both surveys contain several questions regarding the ownership structure of the firms. Using this information, we construct 
the variable Multinational, which takes value one if the firm belongs to a multinational group and zero otherwise.

- Labour costs: another variable of interest in our study is the percentage of total production costs that is accounted for by labour costs. We use the information provided by the surveys in order to create four dummy variables. The first variable takes value one if labour costs are below 25 per cent of total production costs; the second takes value one if they are between 25 and 49 per cent; the third takes value one if they are between 50 and 74 per cent; and the fourth takes value one if they account for 75 per cent or more of production costs. Our reference variable will be the fourth one, so we exclude it from the regressions.

- Internal Labour Markets: we also attempt to control for the influences of internal labour markets on pay settlements. In both data sets, the existence of these markets is measured in terms of the approach to filling vacancies adopted in a workplace. We include a categorical variable that takes value one if internal applicants are the only source when filling vacancies at the workplace, value two if internal applicants are given preference, value three if internal and external applicants are treated equally, value four if external applicants are given preference and value five if external applicants are the only source when filling vacancies.

- Strategic HRM: both questionnaires contain several questions regarding the implication of the establishment's management in personnel matters. With this information, we construct a dummy 
variable that takes value one if there is someone at the plant or organisation's Board of Directors with specific responsibility for employment relations, and zero otherwise. The variable reflects the strategic role of the human resource department.

- Settlement of pay conditions: Spanish managers are enquired about the mechanism that most closely resembles the way in which the pay is set for manual workers. British respondents are asked the same question for each category of employees, and we select the response referring to each establishment's largest occupational group. With this information, we create three dummy variables, which state whether conditions are settled through collective agreement at the plant or firm level, through sectoral agreement or by some other way, respectively. The first variable will be taken as omitted cathegory in the empirical analysis.

- Country: we address the issue of the influence that the country's labour market institutions may have in the determination of pay by including in the analysis a dummy variable that takes value one for British establishments.

\section{Results}

In this section, we report the results of our empirical analysis. Since the dependent variables are dichotomous, we used logit models in our estimations. We estimated four equations, one for each of our dependent variables. Our findings are documented in Table 2. 
Several interesting relationships have been detected. Large establishments are more concerned about the climate of industrial relations when setting payments, which supports the hypothesis that these plants tend to offer better working conditions as well as employment stability. However, we find no significant relationship between workplace size and the ability to recruit and retain employees. Our results show a positive correlation between the age of the establishment and our variables of inflation and performance. Contrary to our thinking, we find no relationship between the number of years in business and the climate of industrial relations.

Controlling for the remaining variables in the model, establishments belonging to a multinational group have a higher probability of considering the cost of living when setting payments than establishments that do not belong to a multinational corporation. On the contrary, they give less importance to their ability to recruit and retain employees, and to their performance in their decisions concerning wage adjustment. These results do not confirm our thinking regarding the influences of foreign ownership on the factors that shape pay settlements.

The absence of an internal labour market within the establishment is positively correlated, as predicted, with the importance given to hiring issues and to the industrial relations environment. The evidence also supports our belief that establishments with low labour costs are more interested in the recruitment and retaining of employees. The variable representing the strategic approach to HRM shows a positive and significant correlation with the performance of the establishment, which sheds light on the idea that this 
approach to HRM implies an alignment of HR practices with the needs of the organisation.

Our hypothesis regarding the influence of the variables that represent the mechanisms of pay setting are generally confirmed by the empirical findings. Establishments affected by a regime of pay determination different than collective bargaining at plant, firm or sector level are less concerned about the cost of living and the climate of industrial relations when setting payments. However, a significant negative relationship between inflation and the existence of a sectoral agreement emerges, suggesting that there are differences in the importance given to the cost of living between establishments with this type of bargaining regime and those where single-employer negotiation takes place.

Finally, our results provide evidence to support the hypothesis that the differences in labour market regulation between countries influence the process of pay determination. However, according to the results obtained, British establishments are less concerned about all the factors we have considered in our analysis of pay settlements, which contradicts our assumption that they should give more importance to the performance of the plant or the firm than Spanish workplaces.

\section{Conclusions}

The present study has attempted to identify the factors that influence pay settlements in Spanish and British establishments. In particular, we have investigated the determinants of the importance given to the cost of living, the ability to recruit and retain employees, the performance of the establishment or the firm, and the climate of industrial relations for pay adjustments. Several 
interesting relationships among the variables analysed here have emerged, and we hope they serve to launch research on this topic.

Overall, the establishment level data provide empirical support to the hypotheses formulated. However, some unexpected relationships have emerged between those establishments belonging to a multinational corporation and our variables of interests. Moreover, the empirical evidence contradicts some of our views concerning the differences in pay settlement between Spanish and British establishments. Clearly, further research on these issues is required in order to properly explain the nature of these relationships. Our results reflect the existence of highly significant differences in pay setting between Spain and the UK. Certainly, labour market institutions matter when it comes to pay decisions. For the moment, our findings support that the SpanishBritish comparison is highly relevant and not only coincidental.

It should be pointed out that this study has several limitations related to the merging of information from two different surveys. On the one hand, Spanish data refers exclusively to establishments belonging to the private sector, whereas British data contain information on both public and private workplaces. Furthermore, the Spanish analysis is limited to establishments with 50 or more employees, while the British sample consists of workplaces with five

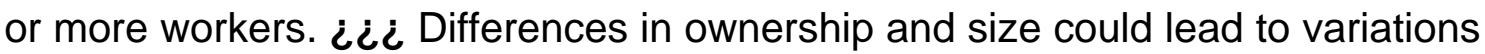
in pay policies between establishments, and future research should try to address this caveat in our study. Finally, it would be interesting to replicate our analysis using data from other countries in order to get a deeper understanding of the influence that institutions exert on pay settlements. 


\section{Acknowledgements}

The authors acknowledge the Department of Trade and Industry, the Economic and Social Research Council, the Advisory, Conciliation and Arbitration Service and the Policy Studies Institute as the originators of the 2004 Workplace Employment Relations Survey data, and the Data Archive at the University of Essex as the distributor of the data. The National Centre for Social Research was commissioned to conduct the survey fieldwork on behalf of the sponsors. None of these organisations bears any responsibility for the author's analysis and interpretations of the data. The authors also thank the Fundacion BBVA for the funding of the survey conducted in the Spanish establishments. This paper has been prepared for the BJIR Conference on Comparative Studies of the Workplace to be held on March 13 and 14 in the Centre for Economic Performance at the London School of Economics. The first and second authors acknowlede financial support from Ministerio de Educacion y Ciencia (projects SEJ2007-66511 and SEJ2005-03470/ECON).

\section{Notes}

1. According to the European Industrial Relations Observatory (2007) in 2005, collective agreements at sectoral and provincial level represented 21 per cent of the total collective agreements and covered 55 per cent of workers, whereas national collective agreements amounted to 1.5 per cent of the total agreements and covered 27.4 per cent of workers. At the same time, company level agreements represented 75 per cent of the total agreements, but covered only 10 per cent of total work force.

2. In 2004 , only 35 per cent of British employees are covered by a collective agreement, compared to 70 per cent on average in Europe (Kersley et al, 2006). 


\section{References}

Arai, M. (2003). “Wages, Profits and Capital Intensity: Evidence From Matched Worker-Firm Data". Journal of Labour Economics, 21 (3):4, 593-618.

Baron, J. N. and Kreps, D. M. (1999). Strategic Human Resources. Frameworks for General Managers. New York: John Wiley \& Sons, Inc.

Belfield, C. R. and Wei, X. (2004)." Employer size-wage effects: evidence from matched employer-employee survey data in the UK". Applied Economics, 38(3): 185-193.

Brickley, J. A., Smith, C. W. Jr and Zimmerman, J. L. (1997). Managerial Economics and Organizational Architecture. Boston, Mass.: Irwin/McGraw-Hill. Brock, W. and Evans, D. (1986). The Economics of Small Business. New York: Holmes \& Meier.

Brown, C. and Medoff, J. L. (2003). "Firm Age and Wages". Journal of Labor Economics, 21 (3): 677-697.

Brown, D., Ingram, P. and Wadsworth, J. (2004). "The Price is Right? Pay Settlements and Nominal Wage Rigidity in Britain". British Journal of Industrial Relations, 42 (3): 507-525.

Bryson, A. and Forth, J. (2006). "The Theory and Practice of Pay Setting". Discussion Paper No. 285, London: National Institute of Economic snd Social Research.

Canal Domínguez, J. F. and Rodriguez Gutiérrez, C. (2004). "Collective bargaining and within-firm wage dispersion in Spain". British Journal of Industrial Relations, 42 (3): 481-506. 
Cardoso, A. R. and Portugal, P. (2003). "Bargained Wages, Wage Drift and the Design of the Wage Setting System". Discussion Paper No. 914, Institute for the Study of Labour (IZA).

Department of Trade and Industry (2005) Workplace Employment Relations Survey:

Cross-Section, 2004 [computer file]. 1st ed. Colchester: The Data Archive [distributor], 21 December 2005. SN: 5294.

European Industrial Relations Observatory (2007). Spain and United Kingdom Industrial Relations Profiles, available online at:

[http://www.eurofound.europa.eu/eiro/country_index.htm].

Farber, Henry (1998). "Are Lifetime Jobs Disappearing? Job Duration in the United States, 1973-1993". In Labor Statistics Measurement Issues, edited by John Haltiwanger and Marilyn Manser, pp. 157-203. Chicago: University of Chicago Press.

Farndale, E. (2005). "HR Department Professionalism: A Comparison Between the UK and Other European Countries". International Journal of Human Resource Management, 16 (5): 660-675.

Forth, J. and Millward, N. (2000). "Pay Settlements in Britain". Discussion Paper No. 173, London: National Institute of Economic and Social Research.

Gooderham, P., Nordhaug, O. and Ringdal, K. (2006). "National Embeddedness and Calculative Human Resource Management in US Subsidiaries in Europe and Australia". Human Relations, 59 (11): 1491-1513.

Hall, Robert (1982). "The Importance of Lifetime Jobs in the U.S. Economy." American Economic Review, 72 (4): 716-724. 
Hamann, K. and Kelly, J. (2003). "The Domestic Sources of Differences in Labour Market Policies". British Journal of Industrial Relations, 41 (4): 639-663. Ingram, P., Wadsworth, J. and Brown, D. (1999). "Free to Choose? Dimensions of Private-Sector Wage Determination, 1979-1994". British Journal of Industrial Relations, 31 (7): 33-49.

Kersley, B., Alpin, C., Forth, J., Bryson, A., Bewley, H., Dix, G. and Oxenbridge, S. (2006). Inside the Workplace: Findings from the 2004 Workplace Employment Relations Survey. London: Department of Trade and Industry.

Kostova, T. and Roth, K. (2002). "Adoption of an Organizational Practice by Subsidiaries of Multinational Corporations: Institutional and Relational Effects." Academy of Management Journal, 45(1): 215-33.

Lallemand, T., Plasman, R. and Rycx, F. (2005). "Why Do Large Firms Pay Higher Wages? Evidence from Matched Worker-Firm Data". International Journal of Manpower, 26: 706-723.

Mesner-Andolsek, D. And Stebe, J. (2005). "Devolution or (De)centralization of HRM Function in European Organizations". International Journal of Human Resource Management, 16 (3): 311-329.

Morton, J. and Siebert, W. S. (2001). "Labour Market Regimes and Worker Recruitment and Retention in the European Union: Plant Comparisons". British Journal of Industrial Relations, 39 (4): 505-528.

OECD (2004). Employment Outlook 2004. Paris: OECD.

Oi, W.Y. and Idson, T.L. (1999), "Firm-size and wages". In Handbook of Labor Economics, Volume 3, edited by Orley Ashenfelter and David Card, pp. 2166214. Elsevier: North Holland. 
Plasman, R., Rusinek, M. and Rycx, F. (2007). "Wages and the Bargaining Regime under Multi-Level Bargaining: Belgium, Denmark and Spain". European Journal of Industrial Relations, 13(2): 161-180.

Poutsma, E., Ligthart, P. E. M. And Veersma, U. (2006). "The Diffusion of Calculative and Collaborative HRM Practices in European Firms". Industrial Relations, 45 (4): 513-546.

Schmidt, C. M. and Zimmerman, K. F. (1991). "Work characteristics, firm size and wages". Review of Economics and Statistics, 73, 705-10.

Schuler, R. S., Jackson, S. E. (2005). "A Quarter-Century Review of Human Resource Management in the U.S.: The Growth in Importance of the International Perspective". Management Review, 16 (1): 1-25.

Werner, S. and Ward, S. G. (2004). "Recent Compensation Research: An Eclectic Review". Human Resource Management Review, 14 (2): 201-227. 


\section{Tables}

Table 1 : Variable Definitions and Descriptive Statistics

\begin{tabular}{|c|c|c|c|}
\hline Variable & Definition & Mean & Std. Dev. \\
\hline Inflation & $\begin{array}{l}\text { Dummy variable: } 1 \text { if changes in the cost of living influence } \\
\text { pay settlements, } 0 \text { otherwise }\end{array}$ & 0.840 & 0.368 \\
\hline Recruitment & $\begin{array}{l}\text { Dummy variable: } 1 \text { if the ability to recruit or retain } \\
\text { employees influence pay settlements, } 0 \text { otherwise }\end{array}$ & 0.640 & 0.482 \\
\hline Performance & $\begin{array}{l}\text { Dummy variable: } 1 \text { if the economic or financial performance } \\
\text { of the organisation or workplace influence pay settlements, } \\
0 \text { otherwise }\end{array}$ & 0.740 & 0.439 \\
\hline Climate & $\begin{array}{l}\text { Dummy variable: } 1 \text { if industrial relations climate influence } \\
\text { pay settlements, } 0 \text { otherwise }\end{array}$ & 0.610 & 0.489 \\
\hline Country & Dummy variable: 1 if United Kingdom, 0 otherwise & 0.240 & 0.425 \\
\hline Size & Number of employees (natural log) & 4.816 & 1.016 \\
\hline Age & Age of the establishment, in years (natural log) & 3.366 & 0.814 \\
\hline Multinational & $\begin{array}{l}\text { Dummy variable: } 1 \text { if the plant belongs to a foreign-owned } \\
\text { firm, } 0 \text { otherwise }\end{array}$ & 0.240 & 0.427 \\
\hline Labour costs $<25 \%$ & $\begin{array}{l}\text { Dummy variable: } 1 \text { if labour costs below } 25 \% \text { of production } \\
\text { costs, } 0 \text { otherwise }\end{array}$ & 0.320 & 0.468 \\
\hline Labour costs $25-49 \%$ & $\begin{array}{l}\text { Dummy variable: } 1 \text { if labour costs between } 25 \% \text { and } 49 \% \\
\text { of production costs, } 0 \text { otherwise }\end{array}$ & 0.470 & 0.499 \\
\hline Labour costs $50-74 \%$ & $\begin{array}{l}\text { Dummy variable: } 1 \text { if labour costs between } 50 \% \text { and } 74 \% \\
\text { of production costs, } 0 \text { otherwise }\end{array}$ & 0.190 & 0.393 \\
\hline Labour costs $>74 \%$ & $\begin{array}{l}\text { Dummy variable: } 1 \text { if labour costs above } 74 \% \text { of production } \\
\text { costs, } 0 \text { otherwise (reference category) }\end{array}$ & 0.168 & 0.374 \\
\hline Internal Labour Markets & $\begin{array}{l}1 \text { if internal applicants are the only source (no external } \\
\text { recruitment), } 2 \text { if internal applicants are given preference, } \\
\text { other things being equal, over external applicants, } 3 \text { if } \\
\text { applications from internal and external applicants are } \\
\text { treated equally, } 4 \text { if external applicants are given } \\
\text { preference, other things being equal, over internal } \\
\text { applicants, } 5 \text { if external applicants are the only source (no } \\
\text { internal recruitment) }\end{array}$ & 1.810 & 1.461 \\
\hline Strategic HRM & $\begin{array}{l}\text { Dummy variable: } 1 \text { if HR professional on Board of Directors, } \\
0 \text { otherwise }\end{array}$ & 0.708 & 0.455 \\
\hline Sectoral agreement & $\begin{array}{l}\text { Dummy variable: } 1 \text { if pay set by collective bargaining at } \\
\text { sectoral level, } 0 \text { otherwise }\end{array}$ & 0.380 & 0.487 \\
\hline Collective agreement & $\begin{array}{l}\text { Dummy variable: } 1 \text { if pay set by collective bargaining at } \\
\text { organisation or plant level, } 0 \text { otherwise }\end{array}$ & 0.460 & 0.498 \\
\hline Other & $\begin{array}{l}\text { Dummy variable: } 1 \text { if pay set some other way, } 0 \text { otherwise } \\
\text { (reference category) }\end{array}$ & 0.160 & 0.365 \\
\hline
\end{tabular}


Table 2. Determinants of Pay Settlements: Logit Models

\begin{tabular}{|c|c|c|c|c|}
\hline Variable & Cost of living & $\begin{array}{c}\text { Ability to } \\
\text { recruit/retain } \\
\text { employees }\end{array}$ & $\begin{array}{c}\text { Performance of } \\
\text { the } \\
\text { organisations } \\
\text { or workplace }\end{array}$ & $\begin{array}{c}\text { Industrial } \\
\text { relations } \\
\text { climate }\end{array}$ \\
\hline Constant & $\begin{array}{c}0.967 \\
(0.871)\end{array}$ & $\begin{array}{c}0.636 \\
(0.704)\end{array}$ & $\begin{array}{c}0.951 \\
(0.736)\end{array}$ & $\begin{array}{l}2.725^{\star \star} \\
(1.110)\end{array}$ \\
\hline Country & $\begin{array}{c}-1.247^{\star \star \star} \\
(0.354)\end{array}$ & $\begin{array}{c}-1.642^{\star \star \star} \\
(0.264)\end{array}$ & $\begin{array}{c}-1.094^{\star \star \star} \\
(0.277)\end{array}$ & $\begin{array}{c}-4.526^{\star \star \star} \\
(0.407)\end{array}$ \\
\hline Size (log) & $\begin{array}{c}0.046 \\
(0.105)\end{array}$ & $\begin{array}{l}-0.038 \\
(0.084)\end{array}$ & $\begin{array}{l}-0.108 \\
(0.089)\end{array}$ & $\begin{array}{l}-0.247^{*} \\
(0.139)\end{array}$ \\
\hline Age (log) & $\begin{array}{l}0.254^{\star \star} \\
(0.127)\end{array}$ & $\begin{array}{l}-0.138 \\
(0.103)\end{array}$ & $\begin{array}{l}0.202^{*} \\
(0.110)\end{array}$ & $\begin{array}{c}0.120 \\
(0.166)\end{array}$ \\
\hline Multinational & $\begin{array}{c}0.822^{\star \star \star} \\
(0.309)\end{array}$ & $\begin{array}{c}-0.638^{\star \star *} \\
(0.193)\end{array}$ & $\begin{array}{l}-0.370^{*} \\
(0.209)\end{array}$ & $\begin{array}{c}0.069 \\
(0.303)\end{array}$ \\
\hline Labour Costs $<25 \%$ & $\begin{array}{c}0.128 \\
(0.679)\end{array}$ & $\begin{array}{l}0.992^{*} \\
(0.560)\end{array}$ & $\begin{array}{c}0.236 \\
(0.575)\end{array}$ & $\begin{array}{l}-0.242 \\
(0.851)\end{array}$ \\
\hline Labour Costs $25-49 \%$ & $\begin{array}{c}0.390 \\
(0.674)\end{array}$ & $\begin{array}{l}1.062^{*} \\
(0.555)\end{array}$ & $\begin{array}{c}0.351 \\
(0.569)\end{array}$ & $\begin{array}{l}-0.118 \\
(0.843)\end{array}$ \\
\hline Labour Costs $50-74 \%$ & $\begin{array}{c}0.059 \\
(0.693)\end{array}$ & $\begin{array}{c}0.920 \\
(0.571)\end{array}$ & $\begin{array}{c}0.664 \\
(0.596)\end{array}$ & $\begin{array}{c}0.088 \\
(0.872)\end{array}$ \\
\hline Internal Labour Markets & $\begin{array}{c}0.023 \\
(0.085)\end{array}$ & $\begin{array}{l}0.136^{\star \star} \\
(0.066)\end{array}$ & $\begin{array}{c}0.047 \\
(0.068)\end{array}$ & $\begin{array}{l}0.174^{\star \star} \\
(0.080)\end{array}$ \\
\hline Strategic HRM & $\begin{array}{c}0.218 \\
(0.225)\end{array}$ & $\begin{array}{c}0.124 \\
(0.177)\end{array}$ & $\begin{array}{l}0.379^{\star \star} \\
(0.189)\end{array}$ & $\begin{array}{c}0.121 \\
(0.276)\end{array}$ \\
\hline Sectoral agreement & $\begin{array}{c}-0.576^{\star \star} \\
(0.290)\end{array}$ & $\begin{array}{l}-0.106 \\
(0.198)\end{array}$ & $\begin{array}{l}-0.275 \\
(0.224)\end{array}$ & $\begin{array}{c}-0.377 \\
(0.270)\end{array}$ \\
\hline OtheR & $\begin{array}{l}-0.631^{*} \\
(0.367)\end{array}$ & $\begin{array}{c}0.217 \\
(0.299)\end{array}$ & $\begin{array}{l}-0.298 \\
(0.307)\end{array}$ & $\begin{array}{c}-2.072^{\star * \star} \\
(0.574)\end{array}$ \\
\hline "Chi-squared" & 71.154 & 92.696 & 60.577 & 540.508 \\
\hline$\%$ correct predictions & 85.5 & 71.0 & 76.0 & 89.7 \\
\hline$N$ & 757 & 755 & 753 & 755 \\
\hline
\end{tabular}

${ }^{* * *} p<0.01,{ }^{* *} p<0.05,{ }^{*} p<0.10$

Note: Standard errors in parentheses 